\title{
Microbial Quality of Wastewater Used in Urban Truck Farming and Health Risks Issues in Developing Countries: Case Study of Ouagadougou in Burkina Faso
}

\author{
Léon W. Nitiema ${ }^{1}$, Savadogo Boubacar ${ }^{2}$, Zongo Dramane ${ }^{2}$, Aminata Kabore ${ }^{1}$, Poda Jean Noël ${ }^{2}$, \\ Alfred S. Traoré ${ }^{\text {, Dayéri Dianou }}{ }^{2 *}$ \\ ${ }^{1}$ Research Center for Biological, Alimentary and Nutritional Sciences, Research and Training Unit, Life and Earth Sciences, Univer- \\ sity of Ouagadougou, Ouagadougou, Burkina Faso; ${ }^{2}$ National Center for Scientific and Technological Researches, Institute for \\ Health Sciences Research, Ouagadougou, Burkina Faso. \\ Email: *dayerid@yahoo.fr
}

Received March 27 ${ }^{\text {th }}, 2013$; revised April 29 ${ }^{\text {th }}, 2013$; accepted May 26 ${ }^{\text {th }}, 2013$

Copyright (C) 2013 Léon W. Nitiema et al. This is an open access article distributed under the Creative Commons Attribution License, which permits unrestricted use, distribution, and reproduction in any medium, provided the original work is properly cited.

\begin{abstract}
Urban truck farming in developing countries appears of great importance to overcome unemployment and poverty. However, the quality of wastewater used for such activity could expose populations to waterborne diseases. The microbial quality of wastewaters used for truck farming in Ouagadougou city, was examined for the presence of bacterial and parasitological fecal indicators during the dry-hot season (May) and the wet season (July) in 2012. The wastewaters of three water reservoirs and two canals intensively used for truck farming were analyzed throughout the study. These indicators were also monitored in waste stabilization ponds during wastewater treatment in 3 plants of the city. For all the selected sampling sites, the concentrations of microbial indicators in water were significantly higher in the dry-hot season compared to the wet one ( $\mathrm{p}<0.0001$ ) and ranged to 2200 - 53,800 CFU/100ml for Escherichia coli, 8200 - 108,400 CFU/100ml for fecal coliforms, 650 - 45,000 CFU/100ml) for fecal streptococcus, and 0 - 2.4 eggs/l for helminthes during the study periods. For wastewater under treatment in waste stabilization ponds, significant microbial concentration drops $(\mathrm{p}<0.0001)$ in the range of $82 \%-100 \%, 78 \%-98 \%, 60 \%-100 \%$ and $82 \%-88 \%$, respectively were recorded between the anaerobic and the maturation ponds. The later results highlighted that improving the refining performances of the waste stabilization ponds technology could help decreasing health risks related to wastewater reuse in urban agriculture for a sustainable development of cities in developing countries.
\end{abstract}

Keywords: Truck Farming; Wastewater; Fecal Pollution; Health Risks; Ouagadougou; Burkina Faso

\section{Introduction}

The rapid development of population, climate changes impact and the increase in the demand of agricultural products led to a high pressure on water resources in the world [1]. Faced with this situation, the research of alternative resources is required. In the context, nowadays wastewaters are particularly focused, due to their availability and their agronomic value [2-7]. Indeed, about 20 million hectares of land are irrigated with wastewaters highly polluted by solid or liquid wastes in the world. Moreover, more than $10 \%$ of the world population consumes aliments issued from cultures irrigated with wastewater and this percentage in more important for popula-

"Corresponding author. tions in arid or semiarid poor countries [8]. The cities of developing countries were characterized during the last years by an exponential increase in population due to natural growth and by a massive rural exodus leading to a densification of urban area, a high pressure on natural resources along with water, and an intensification of poverty [8-10]. Due to the situation of endemic poverty, many poor citizens rescue to wastewater-based agriculture, especially truck farming to survive. According to FAO [11], such practice is ancient and 200 million urban farmers in the world may rescue to partially or not treated wastewater for irrigation. In West Africa, approximately $49 \%$, $38 \%$, and $13 \%$ of wastewater treatment effluents are used for truck farming, horticulture, and fish breeding, respectively [12]. In Burkina Faso, it is estimated to 56 
$\mathrm{m}^{3} /$ day the quantity of wastewater used for truck farming in Ouagadougou, and to 70 ha the area covered by this activity $[13,14]$.

However, wastewater reuse for agriculture prior to treatment exposes populations and the environment as well to health risks $[7,10,15,16]$. Indeed, several epidemiological studies revealed that wastewater or activated sludge reuse are potential sources of chemical and microbiological contaminations of surface water tables $[1,5,12$, 17]. In developing countries, about 3 million die prematurely of waterborne diseases along with a majority of children under 5 years old followed by women and poor populations without access to safe drinking water and adequate sanitation $[12,18]$.

After the presentation of the context of the study and the methodology used, the results obtained will be presented. The quality of wastewaters used in truck farming will be discussed with regard to WHO and national guidelines for wastewater reuse in agriculture $[19,20]$, the health-related potential risks for populations, and the performance of the wastewater treatment technology.

\section{Study Context}

In Ouagadougou city, truck farming next to wastewater storage sites (water reservoir of dam, canal for wastewater collection, pond...) is expanding rapidly. This activity practiced by many poor citizen among which a majority of women (Figure 1) contributes to increase households income and to a lesser extent to wastes recycling and environment sanitation [8,10,14,21,22].

However, despite the positive effect at economic development level and to overcome poverty, truck farming as practiced in Ouagadougou city is problematic because of the microbial quality of wastewater used for irrigation. Indeed, this water which consists of liquid and solid wastes is reused prior to treatment. Due to the complexity of the chemical and microbial components of this water and the high-risk practices, this activity exposes producers, vegetable consumers and the population to health risks $[6,8,9,13,14,16,23]$.

Mindful of the control of health risks for populations related to urban agriculture, we examined the bacteriological and parasitological quality of surface wastewaters used in truck farming in the urban area of Ouagadougou during the dry-hot period (May), the wet season (July), and in waste stabilization ponds of treatment plants in 2012.

\section{Material and Methods}

\subsection{Study Sites}

Eight (8) sites among whose 3 water reservoirs of Ouagadougou dam (Ouaga 1, Ouaga 2 and Ouaga 3), 2 ca- nals collecting wastewaters (Canal UO and Canal CHU), and the anaerobic, maturation and discharge ponds of 3 wastewater treatment plants (Abattoir, Kossodo and 2iE) were selected for the study (Figure 2).

The Kossodo plant is treating wastewaters issued from the industrial zone of Kossodo and the effluents of the Abattoir plant which treats essentially wastewaters of the slaughterhouse of Ouagadougou located in the same area. As for the 2iE treatment plant, it receives wastewaters from the Zone of Ouagadougou University including those of the Canal UO.

The waste stabilization ponds technology is a natural technique allowing refining wastewater through the combined action of microorganisms, algae, and aquatic plants and consists of a slow flow of wastewater through several retention ponds ( 3 to 5). Generally, the ponds comprise an anaerobic pond (AP) intended to decrease the carbon charge, a facultative pond (FP) conceived to refine the organic matter treatment, a maturation pond (MP) allowing the complete elimination of pathogens (bacteria, virus, parasites, helminthes), a storage pond (SP) of the treated water from the MP, and a discharge pond/canal [24,25].

The geographic location of the sampling sites and the main usage of water at the site are described in Table 1 and Figure 1.

\subsection{Water Sampling}

Samples collection was performed in the median part of the stretch of water at the water reservoirs and canals. At the wastewater treatment plants, sampling was performed similarly in the anaerobic and maturation ponds and in the discharge pond/canal as well. Samples were collected aseptically in quadruplicate into sterile glass bottles at the field as describes previously [26]. A total of 56 samples including the ones of water treatment plants were taken and analyzed during the dry-hot period for which water demand and pressure on water sources were particularly high, while 20 samples focusing mainly dam and canal waters were investigated during the wet period. Samples collected at the site were preserved at $4^{\circ} \mathrm{C}$ in cool boxes, carried to the Laboratory of Biology of the Institute for Health Sciences Research and stored in a refrigerator at $4^{\circ} \mathrm{C}$ before analysis.

\subsection{Enumeration of Microbial Indicators of Fecal Pollution}

Bacterial and parasite indicators of fecal contamination (Escherichia coli, fecal Coliforms, fecal Streptococcus, and parasite eggs and/or cysts were enumerated 3 - 4 hours following sampling.

The bacterial indicators were enumerated using the 


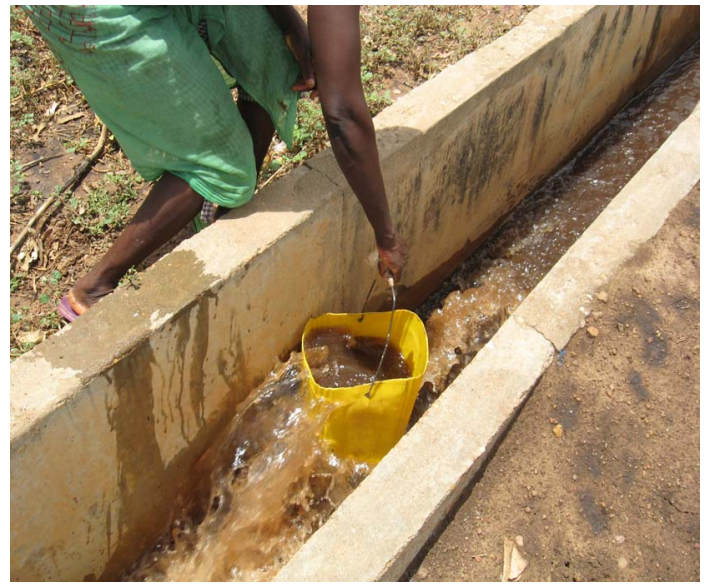

(a)

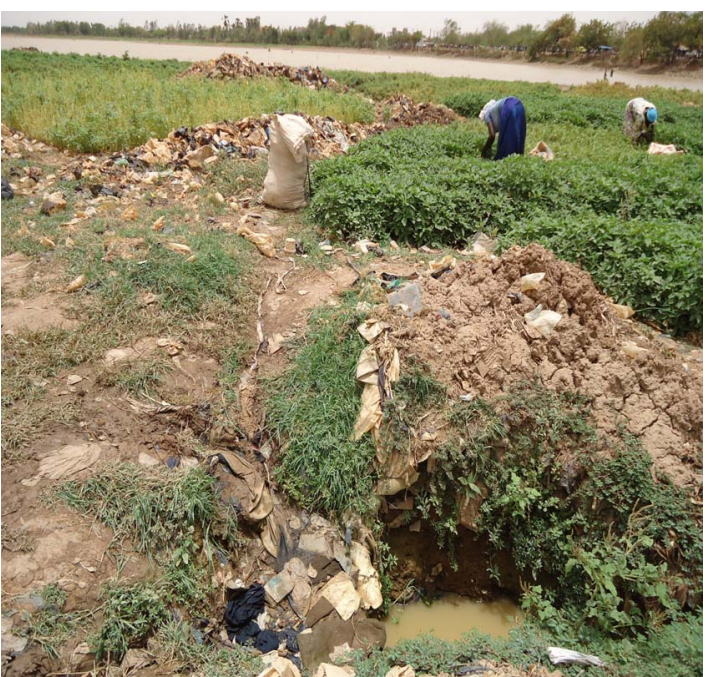

(c)

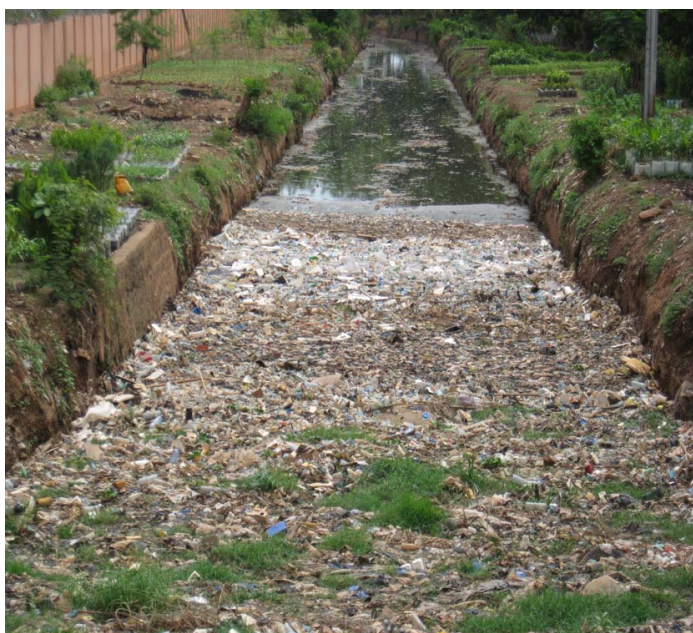

(e)

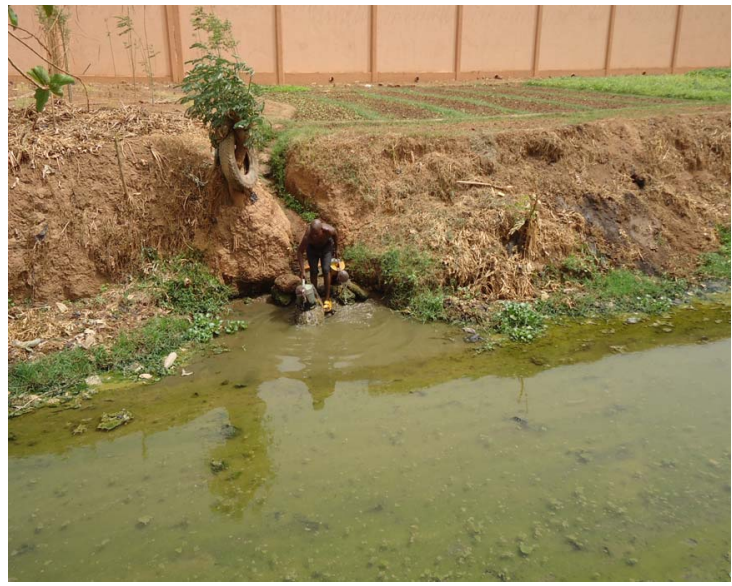

(b)

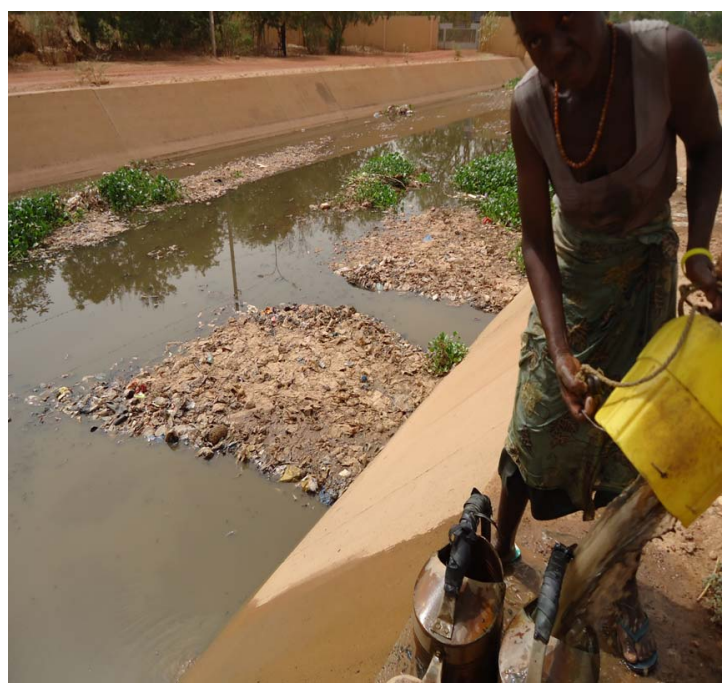

(d)

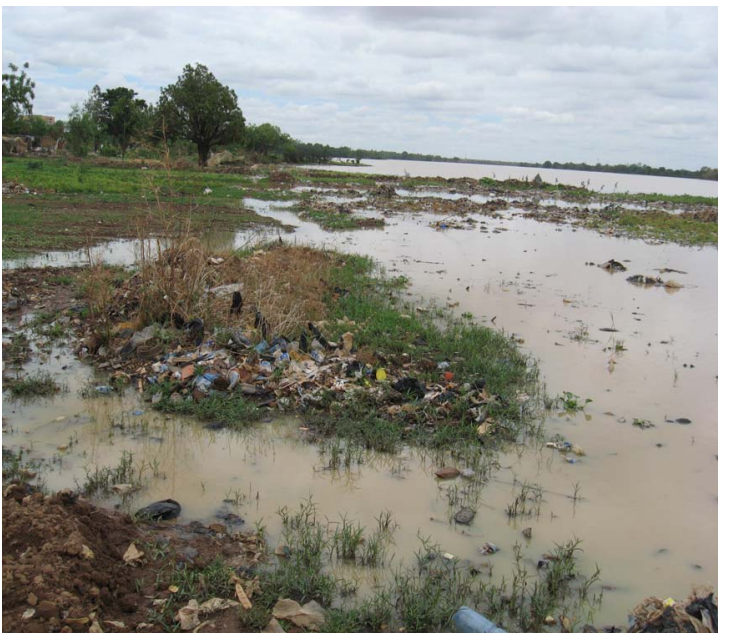

(f)

Figure 1. Water usage at the study sites and some sources of water pollution. (a) Reuse of wastewater treatment effluent from a discharge canal for truck farming at Kossodo; (b) Water sampling from Canal CHU for truck farming; (c) Truck farming site next to the water reservoir of Ouaga $1 \mathrm{dam}$; (d) Water sampling from Canal UO for irrigation; (e) A view of solid waste deposits within Canal CHU; (f) Solid waste deposits within the water reservoir of Ouaga 1 dam. 


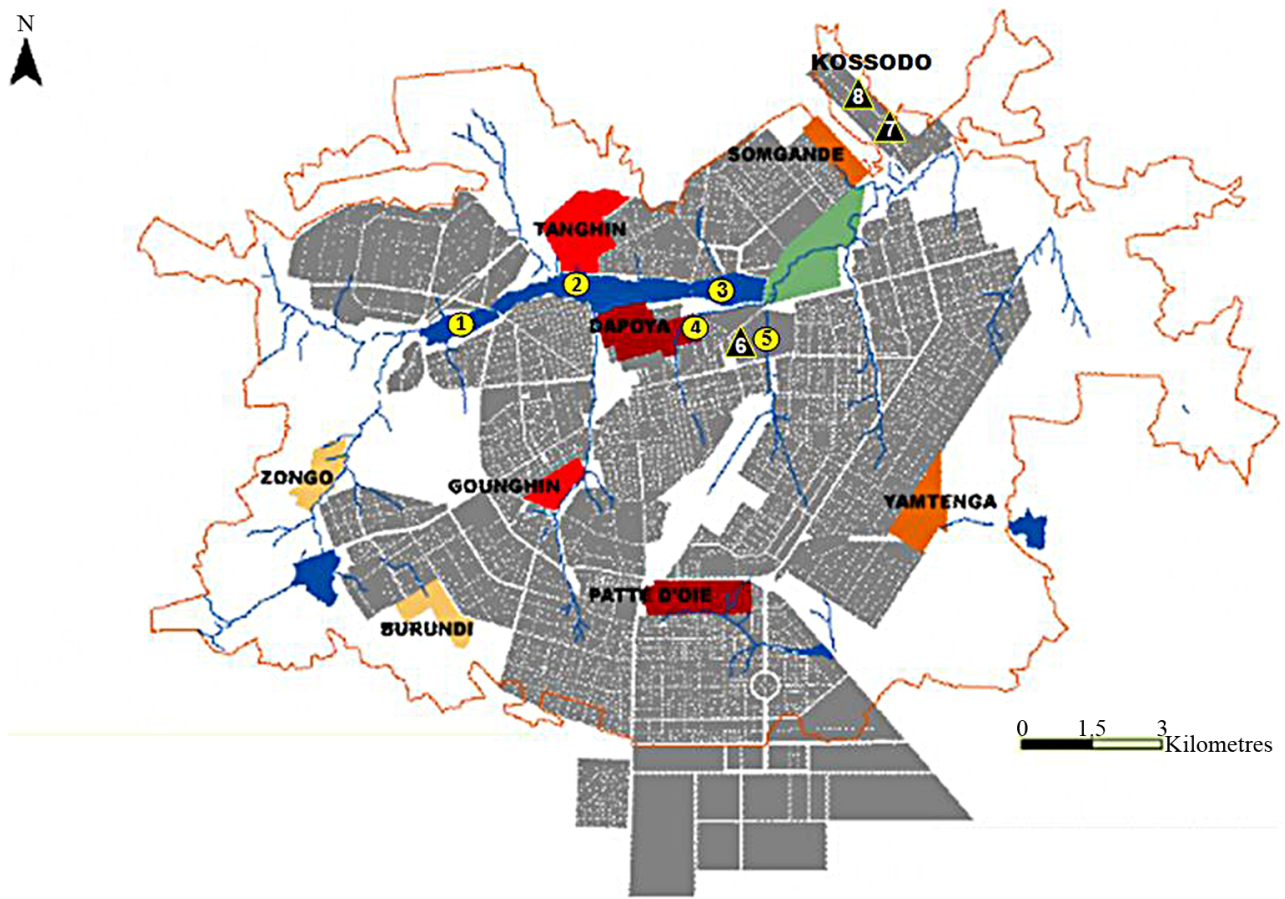

Figure 2. Location of the studied sites. $O=$ Surface wastewater; $\Delta=$ Wastewater treatment plant; $1=$ Water reservoir No. 1 of Ouagadougou dam (Ouaga 1); 2 = Water reservoir No. 2 of Ouagadougou dam (Ouaga 2); 3 = Water reservoir No. 3 of Ouagadougou dam (Ouaga 3); 4 = Canal of the University Hospital Yalgado (CHU); 5 = Canal of the University of Ouagadougou (Canal UO); 6 = Wastewater treatment plant of the International Institute for Water and Environment Engineering (2iE); 7 = Wastewater treatment plant of abattoir; 8 = Wastewater treatment plant of the National Office of Water and Sanitation (Kossodo).

Table 1. Location of the study sites and main usage of water at the site.

\begin{tabular}{|c|c|c|c|}
\hline \multicolumn{2}{|c|}{ Study site/sampling site } & \multirow{2}{*}{$\begin{array}{c}\text { Geographic coordinates } \\
12^{\circ} 25^{\prime} 38.8^{\prime \prime} \mathrm{LN} \\
01^{\circ} 28^{\prime} 51.4^{\prime \prime} \mathrm{LO}\end{array}$} & \multirow{2}{*}{$\begin{array}{c}\text { Water usage } \\
\text { None }\end{array}$} \\
\hline \multirow{3}{*}{ Kossodo plant } & AP & & \\
\hline & MP & $\begin{array}{l}12^{\circ} 25^{\prime} 50.3^{\prime \prime} \mathrm{LN} \\
01^{\circ} 28^{\prime} 35.7^{\prime \prime} \mathrm{LO}\end{array}$ & None \\
\hline & DP & $\begin{array}{l}12^{\circ} 25^{\prime} 41.1^{\prime \prime} \mathrm{LN} \\
01^{\circ} 28^{\prime} 28.3^{\prime \prime} \mathrm{LO}\end{array}$ & Truck farming \\
\hline \multirow{3}{*}{ Abattoir plant } & AP & $\begin{array}{l}12^{\circ} 25^{\prime} 01.4^{\prime \prime} \mathrm{LN} \\
01^{\circ} 28^{\prime} 30.2^{\prime \prime} \mathrm{LO}\end{array}$ & None \\
\hline & MP & $\begin{array}{l}12^{\circ} 24^{\prime} 58.8^{\prime \prime} \mathrm{LN} \\
01^{\circ} 28^{\prime} 32.3^{\prime \prime} \mathrm{LO}\end{array}$ & None \\
\hline & DP & $\begin{array}{l}12^{\circ} 24^{\prime} 58.0^{\prime \prime} \mathrm{LN} \\
01^{\circ} 2831.1^{\prime \prime} \mathrm{LO}\end{array}$ & None \\
\hline \multirow{3}{*}{ 2iE plant } & AP & $\begin{array}{l}12^{\circ} 22^{\prime} 45.9^{\prime \prime} \mathrm{LN} \\
01^{\circ} 30^{\prime} 09.4^{\prime \prime} \mathrm{LO}\end{array}$ & None \\
\hline & MP & $\begin{array}{l}12^{\circ} 22^{\prime} 45.1^{\prime \prime} \text { LN } \\
01^{\circ} 30^{\prime} 09.1^{\prime \prime} \text { LO }\end{array}$ & None \\
\hline & DP & $\begin{array}{l}12^{\circ} 22^{\prime} 46.2^{\prime \prime} \text { LN } \\
01^{\circ} 30^{\prime} 08.0^{\prime \prime} \text { LO }\end{array}$ & None \\
\hline \multicolumn{2}{|c|}{ Canal CHU } & $\begin{array}{l}12^{\circ} 23^{\prime} 06.1^{\prime \prime} \mathrm{LN} \\
01^{\circ} 30^{\prime} 35.9^{\prime \prime} \mathrm{LO}\end{array}$ & Truck farming \\
\hline \multicolumn{2}{|c|}{ Canal UO } & $\begin{array}{l}12^{\circ} 22^{\prime} 57.6^{\prime \prime} \mathrm{LN} \\
01^{\circ} 30^{\prime} 04.9^{\prime \prime} \mathrm{LO}\end{array}$ & Truck farming \\
\hline \multicolumn{2}{|c|}{ Ouaga 1 Dam } & $\begin{array}{l}12^{\circ} 23^{\prime} 00.6^{\prime \prime} \mathrm{LN} \\
01^{\circ} 33^{\prime} 16.8^{\prime \prime} \mathrm{LO}\end{array}$ & Truck farming \\
\hline \multicolumn{2}{|c|}{ Ouaga 2 Dam } & $\begin{array}{l}12^{\circ} 23^{\prime} 19.8^{\prime \prime} \mathrm{LN} \\
01^{\circ} 31^{\prime} 59.2^{\prime \prime} \mathrm{LO}\end{array}$ & Truck farming \\
\hline \multicolumn{2}{|c|}{ Ouaga 3 Dam } & $\begin{array}{l}12^{\circ} 23 ' 26.6^{\prime \prime} \mathrm{LN} \\
01^{\circ} 30^{\prime} 34.6^{\prime \prime} \mathrm{LO}\end{array}$ & Truck farming \\
\hline
\end{tabular}

LN: Latitude North; LO: Longitude West; AP: Anaerobic pond; MP: Maturation pond; DP: Discharge pond. 
membrane filtration technique $[27,28]$ and the chromogenic media RAPID E. COLI 2 AGAR (BIO RAD) for the detection of E. coli and fecal coliforms, and BileEsculine-Azide for fecal Streptococcus count. Bacterial cells were concentrated on a $0.2 \mu \mathrm{m}$ Millipore Membrane Filter followed by culture on the chromogenic media. On the RAPID E. COLI 2 AGAR (BIO RAD) medium which contains 2 substrates specific to the $\beta$-D-Glucuronidase (Gluc) and $\beta$-D-Galactosidase (Gal) enzymes, respectively, after $24 \mathrm{~h}$ incubation period at $44.5^{\circ} \mathrm{C}$, colonies of $E$. coli $\left(\mathrm{Gal}^{+} / \mathrm{Gluc}^{+}\right)$appear violet to pink while other fecal coliforms colonies stain blue. On the BileEsculine-Azide medium, Gram positive cells able to reduce Esculine as fecal Streptococcus stain black after 24 $\mathrm{h}$ incubation period at $37^{\circ} \mathrm{C}$, while Gram negative and other Gram positive cells are inhibited by sodium Azide.

Parasite eggs and/or cysts were identified and enumerated according to Ritchie [29] and consisted of a concentration of parasites with Formalin and Ether followed by a microscopic observation of the precipitate using lens 10 and 40 for the detection of parasite eggs or larva, and lens 100 with immersion oil after addition of two drops of a Iodine-Potassium iodide solution for the research of protozoa cysts.

\subsection{Statistical Method}

Data obtained were analyzed for water source and sampling period variations using the Student's t-test and XLSTAT 7.5.2 statistical software. Mean parameters concentrations were compared according to the Newman Keuls' test.

\section{Results and Discussion}

\subsection{Microbial Quality of Surface Wastewater}

The results of the statistical analysis on the data obtained are presented in Table 2 while the mean characteristics of wastewater are shown in Table 3.

The Student's t-test (Table 2) revealed that all the microbial characteristics of water were significantly related to the sampling site $(\mathrm{p}<0.0001)$ and sampling period as well ( $\mathrm{p}<0.0001)$. The joined effects of site and sampling period affected also significantly $(\mathrm{p}<0.0001)$ these characteristics. The spatial and temporal variations in response to sampling site and sampling period implied that water samples were collected from sources of different microbial characteristics which are more influenced by the period of water collection.

For all the wastewater sources, mean concentrations of microbial pollution indicators (Table 3) were significantly higher $(\mathrm{p}<0.0001)$ in the dry period (May) compared to the wet one (July). Indeed, the dry period sup- ports a very high pressure on water sources for diverse activities along with truck farming (Figures 1(a)-(d)), animals watering, Fishing, washing, and others activities leading to water pollution and a drastic decrease in water table. This situation favors conditions for the proliferation of microorganisms. Conversely, during the wet season, apart from the decrease in activities next to the study sites, the increase in water table due to streaming creates a dilution factor leading to less pronounced microbial concentrations; and that may explain the difference observed between these periods. These findings are in agreement with those recorded for wastewaters in the urban area of Ouagadougou by Nitiéma [7] and in the Sourou valley by Dianou et al. [6].

Globally, relatively high concentrations of Escherichia coli, fecal Coliforms and fecal Streptococcus, respectively were recorded in wastewater samples of the study sites during the dry and wet periods: Canal UO $(53,400$, 108,400 and 45,000 CFU/100ml), Canal CHU (53,800, 71,600 and 43,600 CFU/100ml), Ouaga 2 dam (3330, $35,700$ and $5890 \mathrm{CFU} / 100 \mathrm{ml})$, Ouaga 1 dam (2460, 8200 and $5360 \mathrm{CFU} / 100 \mathrm{ml})$, and Ouaga $3 \mathrm{dam}(2200,11,250$ and $650 \mathrm{CFU} / 100 \mathrm{ml})$. Moreover, wastewater from the dams Ouaga 1, Ouaga 2 and Ouaga 3 which were much more intensively used for truck farming (Table 1), supported also the highest concentrations in parasites (Table 3). High concentrations for the same microbial indicators were also revealed by Cissé [13] and Cissé et al. [14] for wastewaters in the urban area of Ouagadougou and by other authors in other urban cities of developing countries [5,30-33]. Especially, the concentrations of fecal Coliforms (5 - $\left.3000 \times 10^{3} \mathrm{CFU} / 100 \mathrm{ml}\right)$, fecal Streptococcus $\left(1.9-138 \times 10^{3} \mathrm{CFU} / 100 \mathrm{ml}\right)$ and Helminthes $(0$ 37 eggs/L) observed by Kouam et al. [8-10,16] in Yaoundé urban area support fully our findings.

\subsection{Microbial Quality of Wastewater under Refining in Treatment Plants}

The statistical analysis on the data obtained and the mean characteristics of water in the waste stabilization ponds are presented in Tables $\mathbf{4}$ and 5, respectively.

The Student's t-test (Table 4) showed that all the microbial characteristics were significantly related to the treatment plant $(\mathrm{p}<0.0001)$ and the waste stabilization pond as well ( $p<0.0001)$. The joined effects of both factors affected also significantly $(p<0.0001)$ these characteristics.

For all the bacterial indicators of fecal pollution focused in the study and for all the waste stabilization ponds, the treatment plant of Kossodo supported the lowest concentrations $(\mathrm{p}<0.0001)$ compared to the Abattoir and 2iE ones (Table 5). The Kossodo treatment plant 

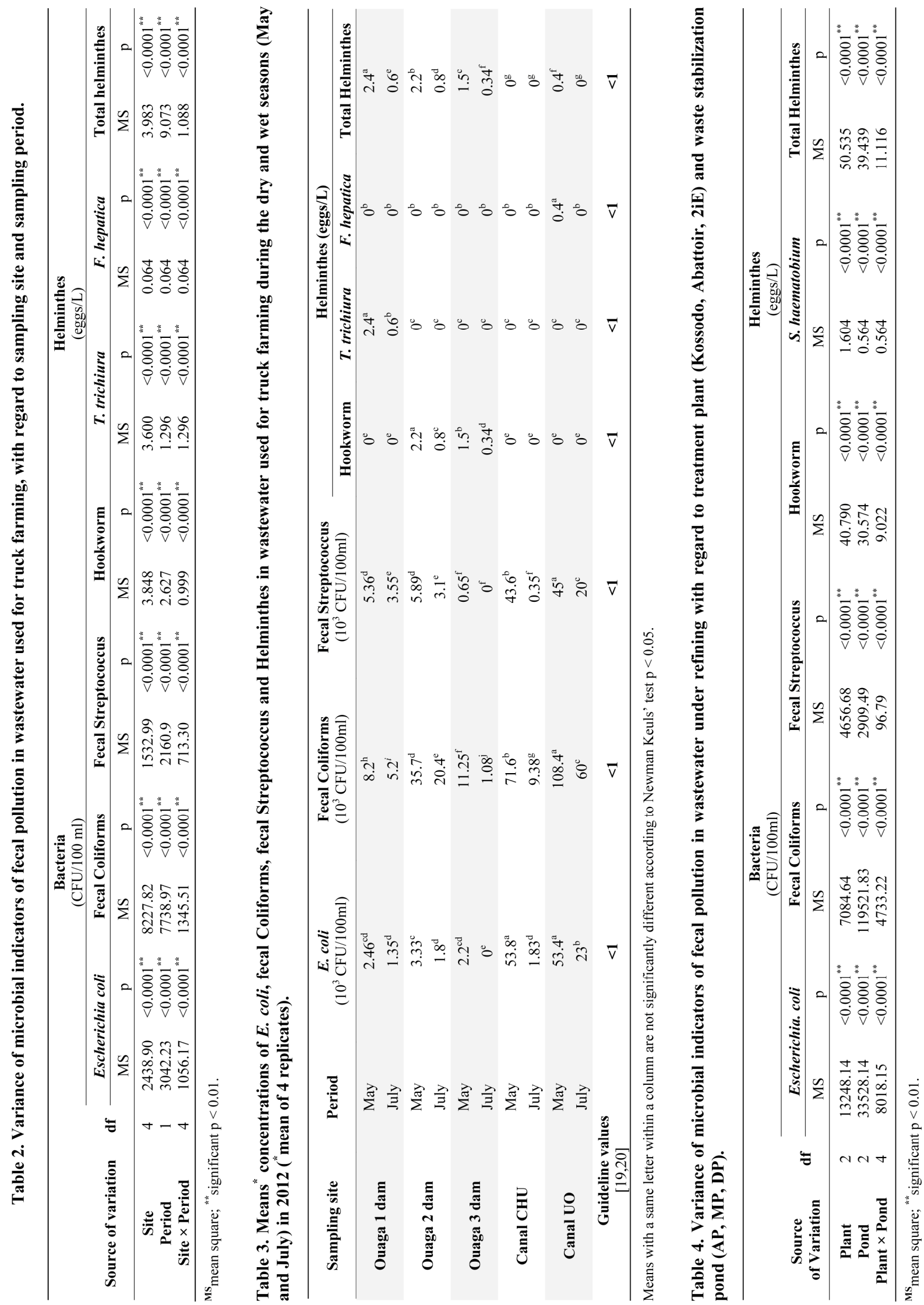
Table 5. Mean* concentrations of $\boldsymbol{E}$. coli, fecal Coliforms, fecal Streptococcus and Helminthes in wastewater under refining at Kossodo, abattoir and 2iE treatment plants during the dry season (May 2012) ("mean of 4 replicates).

\begin{tabular}{|c|c|c|c|c|c|c|c|}
\hline \multirow[t]{2}{*}{ Treatment Plant } & \multirow[t]{2}{*}{ Pond } & \multicolumn{3}{|c|}{$\begin{array}{c}\text { Bacteria } \\
\left(10^{3} \mathrm{CFU} / 100 \mathrm{ml}\right)\end{array}$} & \multicolumn{3}{|c|}{$\begin{array}{l}\text { Helminthes } \\
\text { (eggs/L) }\end{array}$} \\
\hline & & Escherichia coli & Fecal Coliforms & Fecal Streptococcus & Hookworm & S. haematobium & Total Helminthes \\
\hline \multirow{3}{*}{ Kossodo } & AP & $11.2^{\mathrm{e}}$ & $136.2^{c}$ & $22.55^{\mathrm{e}}$ & $5.2^{\mathrm{b}}$ & $1.3^{\mathrm{a}}$ & $6.5^{\mathrm{a}}$ \\
\hline & MP & $0^{\mathrm{h}}$ & $3.2^{\mathrm{i}}$ & $0^{\mathrm{i}}$ & $0.8^{f}$ & $0^{c}$ & $0.8^{\mathrm{e}}$ \\
\hline & DP & $3.3^{g}$ & $23.5^{f}$ & $2.05^{\mathrm{h}}$ & $3.6^{c}$ & $0.6^{\mathrm{b}}$ & $4.2^{\mathrm{c}}$ \\
\hline \multirow{3}{*}{ Abattoir } & AP & $172^{\mathrm{a}}$ & $248.8^{\mathrm{a}}$ & $26.47^{\mathrm{d}}$ & $0^{\mathrm{g}}$ & $0^{c}$ & $0^{\mathrm{f}}$ \\
\hline & MP & $6.45^{\mathrm{f}}$ & $7.3^{\mathrm{h}}$ & $2.8^{\mathrm{g}}$ & $0^{\mathrm{g}}$ & $0^{c}$ & $0^{\mathrm{f}}$ \\
\hline & DP & $10.4^{\mathrm{e}}$ & $14.15^{\mathrm{g}}$ & $3.5^{\mathrm{f}}$ & $0^{\mathrm{g}}$ & $0^{\mathrm{c}}$ & $0^{\mathrm{f}}$ \\
\hline \multirow{3}{*}{$2 \mathrm{iE}$} & AP & $129.2^{\mathrm{b}}$ & $205.2^{\mathrm{b}}$ & $67.2^{\mathrm{a}}$ & $6.2^{\mathrm{a}}$ & $0^{\mathrm{c}}$ & $6.2^{\mathrm{b}}$ \\
\hline & MP & $22.8^{\mathrm{d}}$ & $44.8^{\mathrm{e}}$ & $27.2^{\mathrm{c}}$ & $1.06^{\mathrm{e}}$ & $0^{c}$ & $1.06^{\mathrm{e}}$ \\
\hline & DP & $33.4^{\mathrm{c}}$ & $52^{\mathrm{d}}$ & $36.4^{\mathrm{b}}$ & $2.3^{\mathrm{d}}$ & $0^{\mathrm{c}}$ & $2.3^{\mathrm{d}}$ \\
\hline $\begin{array}{c}\text { Guideline values } \\
{[19,20]}\end{array}$ & & $<1$ & $<1$ & $<1$ & $<1$ & $<1$ & $<1$ \\
\hline
\end{tabular}

Means with a same letter within a column are not significantly different according to Newman Keuls’ test p < 0.05. AP: Anaerobic pond; MP: Maturation pond; DP: Discharge pond.

which belongs to the National Office of Water and Sanitation (ONEA) treats wastewaters from the industrial zone of Kossodo and those already pretreated within industrial units such as Abattoir and the tannery unit TANALIZ located in the same area. This pretreatment of wastewater may partially explain the difference in bacterial concentrations observed between the stabilizations ponds of Kossodo and Abattoir plants.

Globally and independently of the treatment plant, the maturation pond showed the lowest concentrations of bacterial indicators $(\mathrm{p}<0.0001)$, while the highest concentrations were recorded in the anaerobic pond $(\mathrm{p}<$ 0.0001) (Table 5). Significant reductions $(\mathrm{p}<0.0001)$ of $100 \%, 97.65 \%, 100 \%$ and $87.69 \%$ for E. coli, fecal Coliforms, fecal Streptococcus, and total helminthes, respectively were recorded between these ponds at Kossodo plant, while $96.25 \%, 97.07 \%$ and $89.42 \%$ reductions of the bacterial indicators were observed between the same ponds at Abattoir plant (Table 6). These reductions were less important, although significant at the $2 \mathrm{iE}$ plant with $82.35 \%, 78.17 \%$, $59.52 \%$, and $82.90 \%$, respectively for these microbial indicators (Table 6). The high reductions of microbial concentrations in water between the anaerobic and the maturation ponds revealed the good performance of the waste stabilization ponds technology for wastewater refining, especially at Kossodo treatment plant and at a lesser extent at Abattoir and 2iE ones due to some functioning problems during the study period.

However, despite the relatively good performance of the waste stabilization ponds technology, the concentrations of the microbial indicators of fecal pollution after treatment in the maturation pond are not in agreement with the WHO and the national guidelines $[19,20]$ which recommend $<1000 \mathrm{CFU} / 100 \mathrm{ml}$ of fecal Coliforms and fecal Streptococcus, and $<1 \mathrm{egg} / \mathrm{L}$ of total helminthes in wastewater for agriculture and aquaculture. As underlined Koné [34] and Maiga et al. [12,35], the refining performance of waste stabilization ponds technology as practiced in Sahelian zone, is impacted by several environmental factors along with ambient temperature, UV radiations, and pond depth. The inadequacy of these factors may also partially explain the differences observed in the results revealed by the present study. Moreover, a significant recontamination $(\mathrm{p}<0.0001)$ of water was observed from the maturation pond into the discharge pond for all the treatment plants (Table 5). This situation imply the need to create conditions for the improvement and preservation of the water issued from the maturation pond for an appropriate usage of the refined effluent in urban agriculture as suggested by Maiga [12].

\subsection{Truck Farming and Health-Related Risks Linked to Wastewater Quality}

As underlined above, the concentrations of microbial indicators of fecal pollution in wastewater used for trucking farming in Ouagadougou urban area (Table 3) exceeded largely the WHO and the national recommended values $[19,20]$. Moreover, truck farming practices and type of fertilizers used (compost, manure, straw) is potential sources of microbial contaminations for the agricultural products. These situations expose truck farmers, sellers, consumers and all the populations in contact with the wastewaters to high health risks as also revealed Cissé [13], Cissé et al. [14] and Nitiema [7]. Other studies also underlined that wastewater reuse in urban agriculture represents an important health risks factor for 
Table 6. Mean ${ }^{*}$ reduction of $E$. coli, fecal Coliforms, fecal Streptococcus and Helminthes concentrations in wastewater under refining between the anaerobic and the maturation ponds at Kossodo, Abattoir and 2iE treatment plants (" ${ }^{*}$ mean of 4 replicates).

\begin{tabular}{|c|c|c|c|c|c|c|c|c|}
\hline \multirow{3}{*}{ Treatment Plant } & \multicolumn{8}{|c|}{ Microbial indicator } \\
\hline & \multicolumn{2}{|c|}{ Escherichia coli } & \multicolumn{2}{|c|}{ Fecal Coliforms } & \multicolumn{2}{|c|}{ Fecal Streptococcus } & \multicolumn{2}{|c|}{ Total Helminthes } \\
\hline & $\begin{array}{l}\text { Reduction } \\
\text { (\%) }\end{array}$ & $\mathrm{p}$ & $\begin{array}{l}\text { Reduction } \\
\text { (\%) }\end{array}$ & $\mathrm{p}$ & $\begin{array}{l}\text { Reduction } \\
\text { (\%) }\end{array}$ & $\mathrm{p}$ & $\begin{array}{l}\text { Reduction } \\
\text { (\%) }\end{array}$ & $\mathrm{p}$ \\
\hline Kossodo & 100 & $<0.0001^{* *}$ & 97.65 & $<0.0001^{* *}$ & 100 & $<0.0001^{* *}$ & 87.69 & $<0.0001^{* *}$ \\
\hline Abattoir & 96.25 & $<0.0001^{* *}$ & 97.07 & $<0.0001^{* *}$ & 89.42 & $<0.0001^{* *}$ & NF & - \\
\hline $2 \mathrm{iE}$ & 82.35 & $<0.0001^{* *}$ & 78.17 & $<0.0001^{* *}$ & 59.52 & $<0.0001^{* *}$ & 82.90 & $<0.0001^{* *}$ \\
\hline
\end{tabular}

${ }^{* *}$ significant $\mathrm{p}<0.01 ;{ }^{\mathrm{NF}}$ Not found.

populations in developing countries [18,23,36,37]. Indeed, Kouam et al. $[8,16]$ observed an increase of intestinal amoebiasis among truck farmers and truck farming product sellers in Yaoundé, Cameroun.

Other health risks related to wastewater reuse in urban agriculture were not focused in our study, especially those born to the concentrations of heavy metals and pesticides for which the cumulative effects affect populations' health in the long term [19].

\subsection{Some Issues to Control Health Risks Related to Wastewater Reuse in Urban Truck Farming}

Overall, our study findings are supported by the data recorded by Kouam et al. [8-10,16] and Jimenez et al. [38] who showed that the pollution of water in cities of developing countries originated essentially from an inappropriate sanitation and from that, health risks related to wastewater reuse in urban truck farming were amplified by health-risk practices (inappropriate materials for water sampling, permanent contact with wastewater, lack of appropriate methods for vegetable and water disinfection, ...).

In line with that, we examined the quality of wastewaters under refining in treatment plants. The refined waters within the maturation ponds showed a net decrease in microbial indicators of fecal pollution, indicating that the waste stabilization ponds technology for wastewater treatment prior to reuse for agriculture, notably truck farming, may provide an alternative issue for controlling health risks for populations in urban cities of developing countries. However, as also revealed the results obtained, the waste stabilization ponds technology, as practiced in Sahelian countries, especially in the urban area of Ouagadougou, should be improved to meet the WHO guideline values for a non restrictive water reuse for irrigation. For it, the control of environmental parameters such as UV radiations penetration in relation to pond depth as suggested Koné [34] and Maiga et al. [12], integrating a phytorefining system or photosensitizers into the maturation pond according to Kengne et al. [31], Sunda et al.
[39], and Sunda [40], could help improving the refining performance of the technology.

Moreover, the promotion of sanitation and hygiene measures in addition to education on health-risk practices could help reducing health risks related to wastewater reuse in urban agriculture.

\section{Conclusions}

This study evidenced microbial pollutions in wastewater used for truck farming in the urban area of Ouagadougou and related potential health risks for truck farmers and consumers of products issued from this activity as well. Interestingly, the study also revealed that wastewater refining through waste stabilization ponds technology appeared as an alternative issue to reduce and control health risks related to this activity for populations in the urban area of Ouagadougou.

Considering the importance of urban truck farming to overcome unemployment and poverty, and health risks related to this activity, it is highly required to develop appropriate sanitation, in particular wastewater refining for urban agriculture for a sustainable development in urban area of developing countries.

\section{Acknowledgements}

The authors would like to express profound gratitude to ISP-SUEDE/RA-BIOTECH, PACER-UEMOA/RA-BIOTECH, National Office of Water and Sanitation (ONEA) and CNRST/IRSS, for financial and technical supports.

\section{REFERENCES}

[1] World Water Assessment Program, "The United Nations World Water Development Report 3: Water in a Changing World,” UNESCO Publishing, Paris and Earthscan, London, 2009.

[2] G. Hussain, A. J. Al-Saati, "Wastewater Quality and Its Reuse in Agriculture in Saudi Arabia,” Desalinisation, Vol. 123, No. 2-3, 1999, pp. 241-251. doi:10.1016/S0011-9164(99)00076-4

[3] M. Gaye and S. Niang, "Extensive Refining of Wastewa- 
ters for Reuse in Urban Agriculture: Appropriate Technologies in Sahelian Zone to Overcome Poverty," Studies and Researches, ENDA RUP Publishing, 2002, pp. 225227. http://www.enda.sn/rup

[4] K. G. R. Kouam, H. G. Mpakam, S. A. Ndonwy, S. L. D. Bopda and G. E. Ekodeck, "Integrated Management of Water Resources and Millennium Development Goals for the Development of Africa: Case study of Cameroun,” Vertigo, Vol. 7, No. 2, 2006, pp. 1-9.

[5] J. El Addouli, A. Chahlaoui, A. Berrahou, A. Chafi, A. Ennabili and L. Karrouch, "Influence of Wastewaters Used for Irrigation on the Quality of Oeud Bouishak' Waters, Meknes Region (South-Center of Maroc)," Review of Microbiology: Health and Environmental Indicators, Vol. 3 No. 1, 2009, pp. 56-75.

[6] D. Dianou, B. Savadogo, D. Zongo, T. Zougouri, J. N. Poda, H. Bado and F. Rosillon, "Surface Waters Quality of the Sourou Valley: The Case of Mouhoun, Sourou, Debe and Gana Rivers in Burkina Faso,” International Journal of Biological and Chemical Sciences, Vol. 5, No. 4, 2011, pp. 1571-1589.

[7] W. L. Nitiema, "Shea Cake Phenolic Compounds in Water: Pollutant Substances to Eliminate or to be Used as Disinfecting Agents?” Ph.D. Dissertation, University of Ouagadougou, Training and Research Unit, Life and Earth Sciences, 2013, p. 139.

[8] G. R. K. Kouam, F. Rosillon, H. G. Mpakam and A. et Nono, "Health, Socioeconomic and Environmental Aspects Linked to Wastewaters Reuse in Urban Truck Farming: Case Study of Abiergué River-Side (Yaoundé, Cameroun)," Vertigo, Vol. 10, No. 2, 2010, 22 p.

[9] K. G. R. Kouam, F. Rosillon, A. Nono, A. Nzeukou Nzeugang and H. G. Mpakam, "Waterborne Diseases Face to the Management of Water Resources in a Tropical Urban Zone: Case Study of Yaoundé (Cameroun),” European Journal of Water Quality, Paris, 2011, 15 p.

[10] K. G. R. Kouam, F. Rosillon and S. L. Djomou Bopda, "Predisposition of Water Resources Pollution and Socioeconomic, Health and Environmental Impacts in an Urban Zone of a Developing Country: Case Study of Yaoundé (Cameroun),” In: E. Emmanuel, B. Paul, U. Fifi and J. Lacour, Eds., Human Health and Biological Equilibrium of Port-au-Prince Ecosystems: Analysis and Management of Urban and Environmental Risks, University of Quisqueya, 2013, $30 \mathrm{p}$.

[11] Food and Agriculture Organization, "Biological Agriculture can Contribute to Overcome Famine," FAO, Relation Media, Rome, 2007.

http://www.fao.org/newsroom/fr/news/2007

[12] Y. Maïga, K. Denyigba, J. Wethe and A. S. Ouattara, "Sunlight Inactivation of Escherichia coli in Waste Stabilization Microcosms in a Sahelian Region (Ouagadougou, Burkina Faso)," Journal of Photochemistry and Photobiology B: Biology, Vol. 94, No. 2, 2009, pp. 113-119. doi:10.1016/j.jphotobiol.2008.10.008

[13] G. Cissé, "Health Impact of Wastewater Utilization in Urban Agriculture: Case Study of Truck Farming in Ouagadougou,” Ph.D. Dissertation, EPFL, Lausanne, 1997,
$267 \mathrm{p}$.

[14] G. Cissé, M. Kientga, B. Ouédraogo and M. Tanner, "Development of Truck Farming around Water Reservoirs of Ouagadougou Dam: What Are the Health Risks to Take on Board?” Notebooks of Studies and French Speaking Researches, Agriculture, Vol. 11 No. 1, 2002, pp. 31-38.

[15] J. Joly, "Infectiology,” In: M. Gérin, P. Gosselin, S. Cordier, C. Viau, P. Quénel and E. Dewailly, Eds., Environment and Public Health Basis and Practices, Edisem/Tec \& Doc, Acton Vale/Paris, 2003, pp. 145-162.

[16] K. G. R. Kouam, F. Rosillon, A. Nono and H. G. Mpakam, "Health-Related Aspects of Wastewater Reuse in Urban Truck Farming: Case Study of Yaoundé, Cameroun,” In: E. N. Laboy-Nieves, M. F. A. Goosen and E. Emmanuel, Eds., Environmental and Human Health Risk Management in Developing Countries, CRC Press, 2010, pp. 217-234. doi:10.1201/b10540-20

[17] G. Howard, P. Stephen, et al., "Risk Factors Contributing to Microbiological Contamination of Shallow Groundwater in Kampala, Uganda," Water Research, Vol. 37, No. 14, 2003, pp. 3421-3429. doi:10.1016/S0043-1354(03)00235-5

[18] W. Van der Hock, V. Tuan Anh, P. D. Cam, C. Vicheth and A. Dalsgaard, "Skin Diseases among People Using Urban Wastewater in Phnom Penh," Urban Agriculture Magazine, Vol. 14, No. 1, 2005, pp. 30-31.

[19] World Health Organization, "Health Guidelines for the Use of Wastewater in Agriculture and Aquaculture,” Report of a WHO Scientific Group, Technical Report Series 778, World Health Organization, Geneva, 1989, 74 p.

[20] Ministry of Water and Environment, Burkina Faso, "Decree No. 2001-185/PRES/PM/MEE, Fixing the Standards of Pollutants in Air, Water and Soil,” 2001.

[21] United Nations Development Program, “Agriculture: Food, Jobs and Sustainable Cities,” UNDP, New York, 1996, $302 \mathrm{p}$.

[22] C. Broutin, P.-G. Commeat and K. Sokona, "Truck Farming Faced with the Opportunities and Urban Expansion: Case Study of Thiès/Fandène (Sénégal),” Ecocite 2, 2005, 36 p. http://www.ecocite.org

[23] B. Matthys, A. F. Adiko, G. Cissé, K. Wyss, B. A. Tschannen, M. Tanner and J. Utzinger, "The Social Network of Truck Farmers in Abidjan Acts on the Perception of Water-Related Health Risks,” Vertigo, 2006. http://vertigo.revues.org/1857

[24] R. J. Davies-Colley, "Pond Disinfection in Pond Treatment Technology,” In: A. Shilton, Ed., IWA Publishing, London, 2005, pp. 100-136.

[25] R. J. Davies-Colley, R. J. Craggs, J. Park and J. W. Nagels, "Optical Characteristics of Waste Stabilization Ponds: Recommendations for Monitoring," Water Science and Technology, Vol. 51, No. 12, 2005, pp. 153-161.

[26] B. Savadogo, A. Kaboré, D. Zongo, J. N. Poda, H. Bado, F. Rosillon and D. Dianou, "Problematic of Drinking Water Access in Rural Area: Case Study of the Sourou Valley in Burkina Faso,” Journal of Environmental Protection, Vol. 4, No. 1, 2013, pp. 31-50. 


\section{doi:10.4236/jep.2013.41004}

[27] J. Rodier, "Water Analysis: Natural Waters, Wastewaters, Sea Water,” Ed. Dunod, Paris, 2005, p. 1384.

[28] American Public Health Association, American Water Works Association and World Peace Choral Festival, "Standard Methods for the Examination of Water and Wastewater," 20th Edition, American Public Health Association, American Water Works Association and Water Pollution Control Federation, Washington, 1998.

[29] L. S. Ritchie, "An Ether Sedimentation Technique for Routine Stool Examination,” Bulletin. US Army, Medical Department, 1948, $326 \mathrm{p}$.

[30] M. Sonou, "Periurban Agriculture and Health Risks in Ghana,” UAM, Vol. 1, No. 3, 2001, pp. 33-34.

[31] I. M. Kengne, D. Endamana, I. Soh and J. Nya, "Wastewaters Reuse for Urban Agriculture in Yaoundé,” Abstracts of the International Workshop CTA/ETC-RVAF/ CREPA on Wastewater Reuse in Urban Agriculture, Ouagadougou, 3-8 June 2002, pp. 116-123.

[32] P. Moustier and A. S. Fall, "The Dynamics in Urban Agriculture: Caracterization and Evaluation,” In: O. B. Smith, P. Moustier, I. J. A. Mougeot and A. Fall, Sustainable Development of Urban Agriculture in French Speaking Africa: Stakes, Concepts and Methods, CIRAD and CRDI, 2004, pp. 23-29.

[33] A. P. Nguegang, "Urban and Periurban Agriculture in Yaoundé: Multifunctional Analysis of an Expanding Activity for Survival Economy,” Ph.D. Thesis, University of Bruxelles, 2008, 200 p.

[34] D. Koné, "Wastewater Refining through a Microphytes and Macrophytes (Pistia stratoites) Based Waste Stabili- zation Ponds Technology in West and Centre Africa: Report, Refining Performances and Base of Proportioning," Ph.D. Thesis, No. 2653, EPFL, Lausanne, 2002, pp. 17, 30-31.

[35] A. H. Maiga, Y. Konaté, J. Wethe, K. Denyigba, D. Zoungrana and L. Togola, "Refining Performances of a ThreePonds Microphytes Waste Stabilization Microcosms Treatment under Sahelian Climate: Case Study of the 2iE Wastewater Treatment Plant," Journal of Water Sciences, Vol. 24, No. 4, 2008, pp. 399-410.

[36] E. Obuobie, B. Keraita, G. Dansa, P. Amoah, O. Cofie, L. Raschid-Say and P. Drechsel, "Irrigated Urban Vegetable Production in Ghana: Characteristics, Benefits and Risks," Iwmi-Ruaf-Cpwf, Iwmi, Accra, 2006.

[37] T. Rukowski, L. Raschid-Say and S. Buechler, "Wastewater Irrigation in the Developing World. Two Cases Studies from Katmandu Valley in Nepal," Agricultural Water Management, Vol. 88, No. 1-3, 2007, pp. 85-91.

[38] B. Jimenez, D. Mara, R. Carr and F. Brissaud, "Wastewater Treatment for Pathogen Removal and Nutrient Conservation: Suitable Systems for Use in Developing Countries,” In: P. Dreschsel, C. A. Scott, L. Raschid-Sally, M. Redwood and A. Bahri, Earthscan/Iwmi/Irdc, Eds., Wastewater Irrigation and Health, 2010, 342 p.

[39] M. Sunda, F. Rosillon and K. M. Taba, "Contribution to Water Disinfection through Photosensitization with Plant Extracts," Environment Journal of Water Quality, Vol. 39, No. 2, 2008, pp. 199-209. doi:10.1051/water/2008006

[40] M. Sunda, "Contribution to Water Disinfection through Photosensitization with Plant Extracts”, Ph.D. Dissertation, Faculty of Sciences, University of Liège, 2012, 160 p. 